\title{
Um cirurgião sob o olhar de Deus
}

\author{
Eberval Gadelha Figueiredo ${ }^{1}$ Manoel Jacobsen Teixeira ${ }^{1}$
}

1 University of São Paulo, São Paulo, Brazil

Arq Bras Neurocir 2022;41(1):e94.

"Ao trazermos o sagrado para a nossa mesa de trabalho $e$ para as nossas mesas cirúrgicas, elas se tornam um altar."

In this book Um cirurgião sob o olhar de Deus ${ }^{1}$ (- Fig. 1), one of the most influential Brazilian neurosurgeons, Professor Raul Marino Jr. provides us with an insightful and inspirational report of his bright carrier. At the same time correlates it with an introduction for brain/mind sciences and spiritual issues as well. Professor Marino is former Chairman of Neurosurgery and Full Professor of Ethics and Bioethics at the University of Sao Paulo, Brazil.

Aside from tracing each step of his neurosurgical trajectory, this humanistic book may serve as a reflection and a valuable contribution to the true practice of medicine, centered on the human being, which, nowadays, increasingly distances itself from the fundamental human values that created it. This book also enhances the value of the spiritual practice of medicine in general and neurosurgery, in particular. It represents an ignition of a simple spark of utopia within our daily outraged practice. Just others utopias in the history of humanity, it can one day become a reality and an inextinguishable light to illuminate our steps and paths.

Um cirurgião sob o olhar de Deus, by Professor Raul Marino $\mathrm{Jr}$., is unique and a must-read book for all generations of Brazilian neurosurgeons.

Conflict of Interests

The authors have no conflict of interests to declare.
Address for correspondence Eberval Gadelha Figueiredo, MD, PhD, Hospital das Clinicas FMUSP, Rua Eneas C Aguiar, 253, São Paulo, São Paulo, Brazil (e-mail: ebgadelha@yahoo.com).

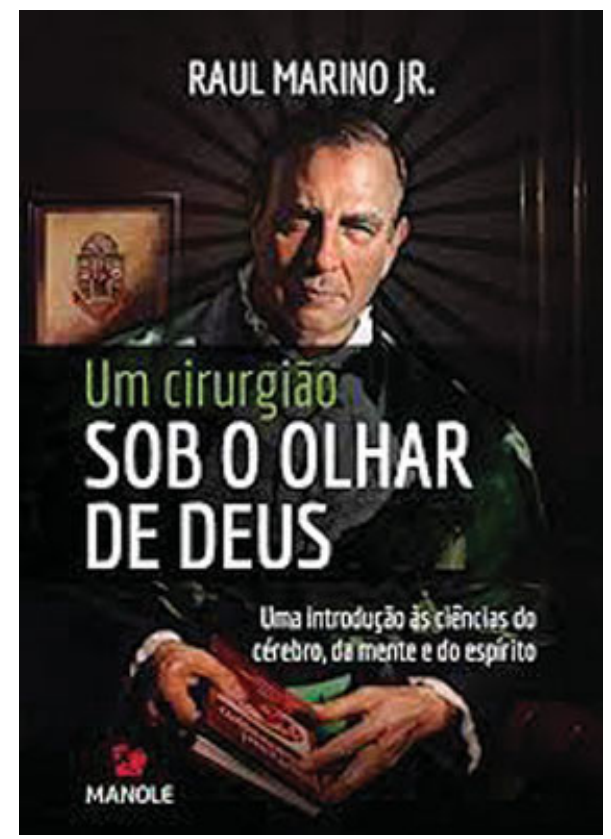

Fig. 1 Um cirurgião sob o olhar de Deus, by Prof. Dr. Raul Marino Jr.

\section{Reference}

1 Marino R Jr. Um cirurgião sob o olhar de Deus. -1 ed - Barueri -SP. Manole, 2020 Conflict of Interest None declared.
DOI https://doi.org/ $10.1055 / \mathrm{s}-0042-1743468$ ISSN 0103-5355.

\footnotetext{
(c) 2022. Sociedade Brasileira de Neurocirurgia. All rights reserved. This is an open access article published by Thieme under the terms of the Creative Commons Attribution-NonDerivative-NonCommercial-License, permitting copying and reproduction so long as the original work is given appropriate credit. Contents may not be used for commercial purposes, or adapted, remixed, transformed or built upon. (https://creativecommons.org/ licenses/by-nc-nd/4.0/)

Thieme Revinter Publicações Ltda., Rua do Matoso 170, Rio de Janeiro, RJ, CEP 20270-135, Brazil
} 